総＼cjkstart説（Review Article）：膜 (MEMBRANE), 27 (4), 164-169（2002）

\title{
特集 日本膜学会第24年会特別講演
}

\section{膜物性による生体膜機能の制御：測るから見るへ \\ 大木 和夫}

東北大学大学院理学研究科物理学専攻 $\overline{7} 980-8578$ 宮城県仙台市青葉区荒巻字青葉

\section{Regulation of Biomembrane Function by Physical Properties of The Membrane: Methodological Change from 'To Measure' to 'To See'}

\begin{abstract}
Kazuo Ohki
Department of Physics, Graduate School of Science, Tohoku University, Aza-Aoba, Aramaki, Aoba-ku, Sendai 980-8578, Japan

The cell, which is a fundamental unit of the life, has been constructed of biomembranes. The inside of the cell in which the complicated chemical reaction progresses has been divided three-dimensionally by the biomembranes which are mainly composed of proteins and lipids. The function appears on membrane protein by the interaction with the lipid and is affected by the physical property of membrane lipid. In the cell, various biological phenomena occur in the regions divided by the biomembranes. Image analysis system under the microscope makes it possible to obtain spatial and time-related information of the biological phenomena in order to clarify the biological system of cell. We have developed the equipment that images the physical property of the biomembrane at video rate under the microscope using fluorescence dye Laurdan. This equipment was applied to the analysis of the fluidity change of the cell membrane of PC12 cell in the apoptosis process. And, it was applied to Giant liposome prepared for bilayer mixture of DMPC and DMPE, and the phase separation phenomenon was observed at the video rate.
\end{abstract}

Key words : physical property $/$ microscopic imaging / lipid-protein interaction $/$ non-bilayer forming lipid

\section{1.はじめに}

地球上の生命は細胞を基本単位としており, 単 細胞生物だけでなく，多細胞生物もその周囲を環 境とする影響下に細胞は存在している。細胞を構 築する生体膜は区画性と選択的な透過性を備え, 制御された化学反応システムである細胞内に細胞 小器官と呼ばれる多様な化学反応槽を形成してい る. 1972年にSingerと Nicolsonが提唱した“流動モ ザイク膜モデル ${ }^{1}$ ' は生体膜の動的な構造の概念か
ら生物機能との関連を考察する端緒となった. 生 体膜は蛋白質と脂質を主要な構成成分とし, 膜脂 質分子はその両親媒性のため, 水分子の水素結合 による疎水性効果で, 二重層膜構造に集合する。 生体膜の機能は第一義的にはDNAの遺伝情報に 従って合成された蛋白質によっているが, 膜蛋白 質の活性には脂質が要求され, 活性は多かれ少な かれ，脂質との相互作用の影響下にある2 . 膜脂 質の分子量は大きくても 1,000 程度であり, 多数 の分子が集合して形成する脂質二重層膜は流動性 
(粘性の逆数に相当), 相転移, 相分離などの物性 を示す。すべての物性は温度依存性であり，温度 変化に対して生物機能を維持する恒常性が進化の 過程で遺伝情報として蓄積されており, 恒温生物 由来の細胞でさえも, 環境温度の変化に応答する。 細胞の温度適応機構として, 脂質二重層膜の温度 依存的な物性が及ぼす効果から生体膜機能を解明 する研究が広く行われた ${ }^{3)}$. 一方, 多細胞生物は 膨大な数の細胞の働きを制御し個体としての調和 を保っているが, 個々の細胞はホルモン系と神経 系のいずれでも, 細胞表面の形質膜に存在する受 容体がリガンドを結合して, 細胞の情報伝達系が トリガーされている．細胞の温度適応機構が物理 的な因子への応答とすれば，これは化学的な因子 への細胞応答である。受容体で得た化学的因子に よる信号は細胞内の各種システムに伝達されて機 能制御が行われるが，ここで，脂質分子が関与し た信号伝達系が，生体膜との関連で注目される4). シグナリング機構の解明には細胞内での信号伝達 を空間的・時間的に解析することが必要となる. ところで, 光学顕微鏡は伝統的に細胞の観察に使 用されてきたが, 近年, その技術革新は著しく, レーザー光源の利用，エレクトロニクス技術によ るカメラの高性能化, コンピューターによる画像 処理などで光学顕微鏡観察システムの性能が画期 的に向上している。既に, 医療分野ではX線-CT, MRIなどの画像診断技術が実用化されているが, ここでは膜物性による生体膜の機能制御の研究が 総体的な（バルクの）測定方法から画像化技術を 用いたシステムの時間的・空間的な相互関係の解 析への方向となっていることを踏まえて生体膜の 構造・物性と機能との相関についての研究を紹介 する。

\section{2. 生体膜の構造と物性による生体膜機能の発現と制御}

生物機能は遺伝情報に従って合成された蛋白質 が担っており, 生体膜もその例外ではない. 生体 膜の動的な構造の提唱により，膜流動性と機能と の関係を解明するために, スピンラベル法や蛍光 偏光解消法などで, 生体膜や人工膜で広く膜流動

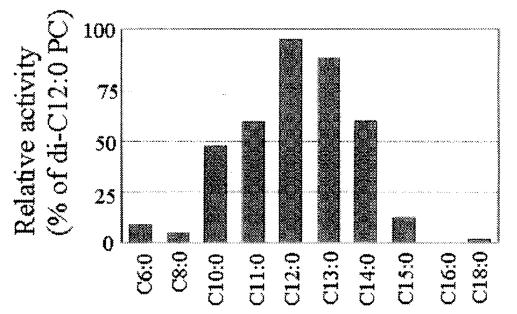

Acyl chain of reconstituted PC

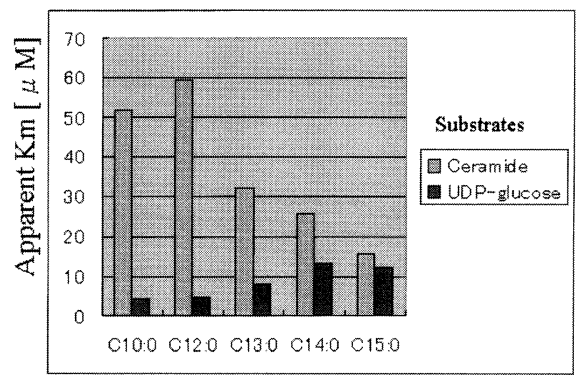

Acyl chain of reconstituted $\mathrm{PC}$

Fig. 1 Enzyme activity of UDP-glucose :ceramide glucosyl transferase reconstituted in various phosphatidylcholine membranes.

UDP-glucose :ceramide glucosyl transferase was purified from membrane fraction of rat brain by CHAPS and DEAE-Toyopearl and then reconstituted with various phosphatidylcholines. Top: Activity of the enzyme reconstituted in various phosphatidylcholine molecules. Bottom: Apparent Michaelis constant $(\mathrm{Km})$ for the each substrate (Nomura and Ohki in preparation).

性の測定が行われた。膜流動性が生体膜の機能を 制御している例として，アドレナリンがその受容 体に結合し，アデニル酸シクラーゼを活性化する 機構で, シクラーゼの活性化が生体膜の粘度に依 存し, 拡散速度が律速となっていることが示され $た^{5)}$. 生体膜の脂質二重層内に組み込まれて存 在する内在性膜蛋白質は周囲の脂質と疎水性相互 作用しており，とくに，蛋白質の周囲を取り巻く 輪状脂質(annular lipid) はこの相互作用により脂 質分子の運動が強く制限されており, boundary lipidとも呼ばれている ${ }^{6}$. 膜蛋白質表面の疎水性 アミノ酸領域と膜脂質の疎水性側鎖との長さが一 致するとき熱力学的に安定な構造となることが理 論的7にも実験的8,9にも示されている。生体膜の 
厚さは構成する脂質の脂肪側鎖の長さで決定され ることから，生体膜の酵素活性が脂質二重層膜の 厚さに依存していることが, $\mathrm{Ca}^{2+}-\mathrm{ATPase}{ }^{10)}$, CTP : ホスホコリンーシチジル酸転移酵素 ${ }^{11}$, 乳 酸球菌のロイシン輸送系 ${ }^{12}$ など一連の膜蛋白質で 示されている。これは膜蛋白質表面の疎水性部分 が脂質二重層膜の疎水性領域と相互作用すると き，両者が整合するように，構造の歪みが生じる ためと考えられる，つまり，膜蛋白質に生じた変 形が酵素活性の変化として測定されている. 著者 らも脂質膜の厚さと酵素活性の関係をUDP-グル コース:セラミドグルコース転移酵素を脂肪酸側 鎖の単数が6から 18 までの長さが異なるホスファ チジルコリン膜に再構成して調べた。 その結果, 炭素数12のとき酵素活性がピークとなり, ミカエ リス定数の測定ではセラミドを基質としたとき炭 素数15まで上昇するのに対して, UDP-グルコー スを基質とすると炭素数 $12 て ゙$ 最大となるこが明ら かになった(Fig.1).一方, 脂質二重層膜の厚さが 変化する相転移として，アルコールなどの添加で ホスファチジルコリンの脂質二重層膜に惹起され る指組み構造への転移 ${ }^{13,14)}$ があるが, 生体膜の機 能との関連はまだ知られていない.ところで, 生 体膜の基本構造は脂質二重層膜であるが, 膜脂質 分子には非二重層構造を形成する分子種が存在す る. 最近, 非二重層構造形成脂質の役割が解明さ れつつあり，大腸菌膜の主要な脂質が非二重層形 成脂質のホスファチジルエタノールアミンである 理由が脂質膜の側方圧力を高膜蛋白質の構造を 安定させることであると提唱された ${ }^{15)}$. 実際に, 酵素活性との関連が調べられ, 膜蛋白質の機能が 非二重層形成脂質により活性化されることが示され ている16. チラコイドやミトコンドリアの膜は蛋 白質の割合が高いが，同時に非二重層形成脂質も 多く含まれている。蛋白質の割合が高いために, 非二重層形成脂質が存在しても二重層膜構造を維 持しているが，膜蛋白質の分解や集合で蛋白質の 割合が低下するとその部分は非二重層構造のキュ ービック相やへキサゴナルII相を形成し，これら は膜脂質供給の貯蔵槽となるとの仮説が提唱され ている ${ }^{17)}$. 非二重層形成脂質とは, 熱力学的な脂
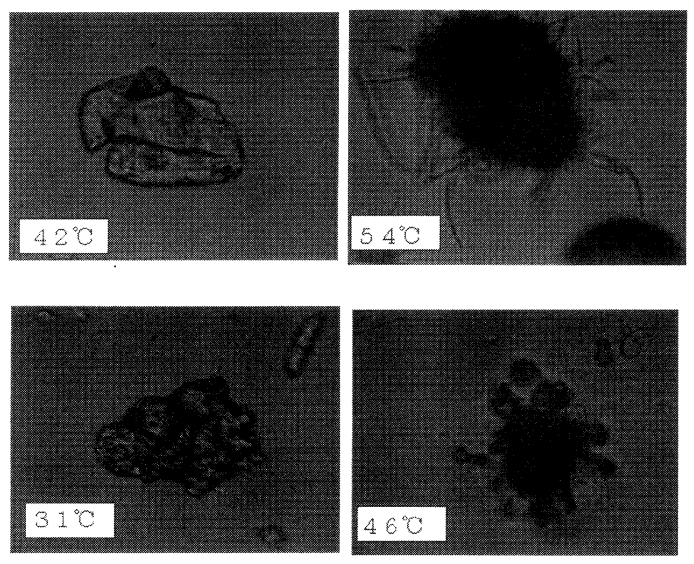

Fig.2 Hydration of two types of phospholipids: Non-bilayer forming lipid and bilayer forming lipid.

Phospholipid powder was placed on a slide glass and water was dropped on it. Hydration was started by heating up the sample above phase transition temperature. Hydration process was observed by an optical microscope equipped with CCD camera and video recorder. Top; Dimyristoylphospahtidylethanolamine (DMPE, $\mathrm{Tm}=50^{\circ} \mathrm{C}$ ), Bottom; Dipalmitoylphosphatidylcholine (DPPC, $\mathrm{Tm}=42$ $\left.{ }^{\circ} \mathrm{C}\right)$

質分子の自己集合過程で，キュービック相やへキ サゴナルII相を形成する脂質であり, Israelachvili らは脂質分子の形状と集合体の形態の関係式を理 論的に求めていた ${ }^{18)}$. 彼らは円柱型の形状をもつ 脂質分子が脂質二重層膜となり生体膜の基本構造 を形成するのに対して, 円錐型の脂質分子が非二 重層形成脂質になると分類した。

\section{3. 非二重層形成脂質による曲率変化と生体膜}

生体膜を構成する脂質成分は多様な分子種から なり，その構造も千差万別であるが，非二重層形 成脂質は円錐型の共通構造をもっており, それら の分子は脂質二重層膜内で集合体は曲率を高める 効果をもっている. 実際に, リン脂質の水和過程 を顕微鏡下に観察すると非二重層形成脂質のホス ファチジルエタノールアミンは二重層形成脂質の ホファチジルコリンに比較して径が細いミエリン 形成の部分が観察されており (Fig.2), 脂質集合体 のレベルでの効果と考えられる．生体成分となる 

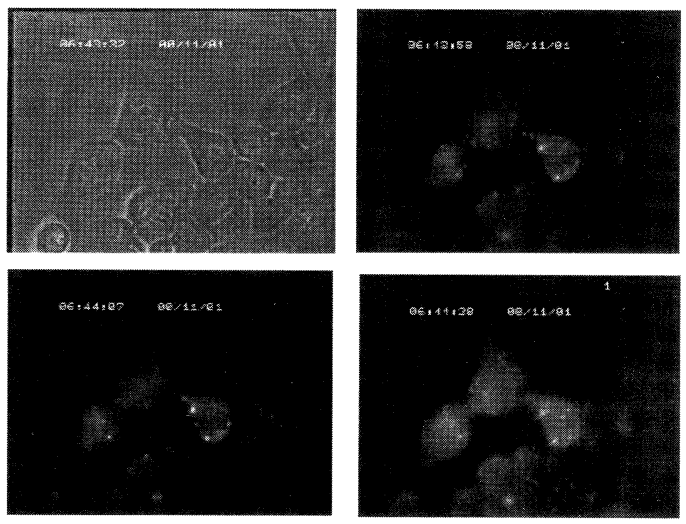

Fig.3 Endocytosis-like phenomenon induced by sphingomyelinase treatment $\mathrm{CHO}$ cells were changed to energy deficient state by adding energy poisons (deoxy-d-glucose and sodium azide), and then treated with sphingomyelinase in the presence of rhodaminedextran. Endocytosis-like phenomenon was observed by fluorescence microscope equipped with CCD camera and digital video recorder.

Top left: Phase contrast image of the CHO cells in energy deficient state. Top right, bottom left and bottom right: Fluorescence images of $\mathrm{CHO}$ cells treated with sphingomyelinase in the order of time course. The second image was taken after $9 \mathrm{sec}$ and the third one was taken after $30 \mathrm{sec}$ of the first image.

分子はすべて細胞の代謝経路の中にあるが，細胞 の機能と関連して酵素の活性化による代謝の促進 が広く観察されている。イノシトールリン脂質が ホスホリパーゼCによってジアシルグリセロール に変換されるホスファチジルイノシトール・サイ クルは二重層形成脂質から非二重層形成脂質への 変換と見なせる ${ }^{19}$. また，スフィンゴミエリン・ サイクルでもスフィンゴミエリナーゼによるスフ インゴミエリンのセラミドへの代謝が非脂質二重 層形成脂質への変換となっている。この変換と生 体膜機能との関連については, $\mathrm{CHO}$ 細胞をスフ インゴミエリナーゼで処理してスフィンゴミエリ ンをセラミドに変換させるとATPを必要としない エンドサイトーシス類似の現象が生じることが報 告され ${ }^{20)}$, 我々も追試により確認した(Fig.3)。一 方，エンドサイトーシスと生体膜の湾曲の関係に ついては生体膜の外層と内層の間で脂質を移行さ せるフリッパーゼの関与をDevauxが提唱してい
たが21)，ホスファチジルセリンのフリッパーゼ久 損したCHO細胞の変異株を取得してエンドサイ トーシスとの相関を調べたところ，フリッパーゼ が久損した株22 ではエンドサイトーシス活性が低 下することが確認できた23.

\section{4. 生体膜の物性を顕微鏡下に観察する方法の開発}

生体膜は細胞を構成する要素として，3次元的 な区画を作ることで，立体的な細胞機能を発現さ せ制御している．細胞の情報伝達系で中心的な役 割を担うプロテインキナーゼCは細胞質に存在す る非活性型が，ジアシルグリセロールと $\mathrm{Ca}^{2+}$ 存 在下にホスファチジルセリンを含む生体膜に結合 して活性型になる ${ }^{24)}$. その過程 ${ }^{25)}$, および, 酵素 の擬基質配列ペプチドがホスファチジルセリンの 相分離を誘起する現象 ${ }^{26)}$ が顕微鏡下に観察され た。細胞は複雑な情報処理システムとして時間 的・空間的なプロセスで機能が発現してお゙り，そ の過程を“見る”研究が重要になっている。 そこ で, 光学顕微鏡下に生体膜の物性の变化を画像と して見る装置を開発した。その原理は生体膜に導 入された環境感受性蛍光色素Laurdanが生体膜の 流動性に対応して水が膜内に浸入する程度をその 蛍光スペクトルに反映させることを利用した27. つまり, Laurdanの発光ピークが疎水性（非極性） 環境の $440 \mathrm{~nm}$ から水 (極性) 環境の490 nmにシ フトするので, 両波長の画像を取得し, これから Generalized Polarization (G.P.; 一般化極性值)の画像 を求める.この装置は発光波長のシフトを用いて いる点に特徵があり，ビデオレートで録画した画 像の処理によりリアルタイム観察が可能である (Fig.4).

\section{5. 膜物性顕微鏡画像化装置の細胞への適用}

開発したこの装置を神経成長因子(NGF)に応答 して神経突起を進展させるPC12D細胞に適用し て, 膜物性の変化を観察した。 その結果, 細胞体 部分でNGF処理直後にGP值の低下, つまり, 膜 流動性の上昇が一過性に生じることが示された28). 


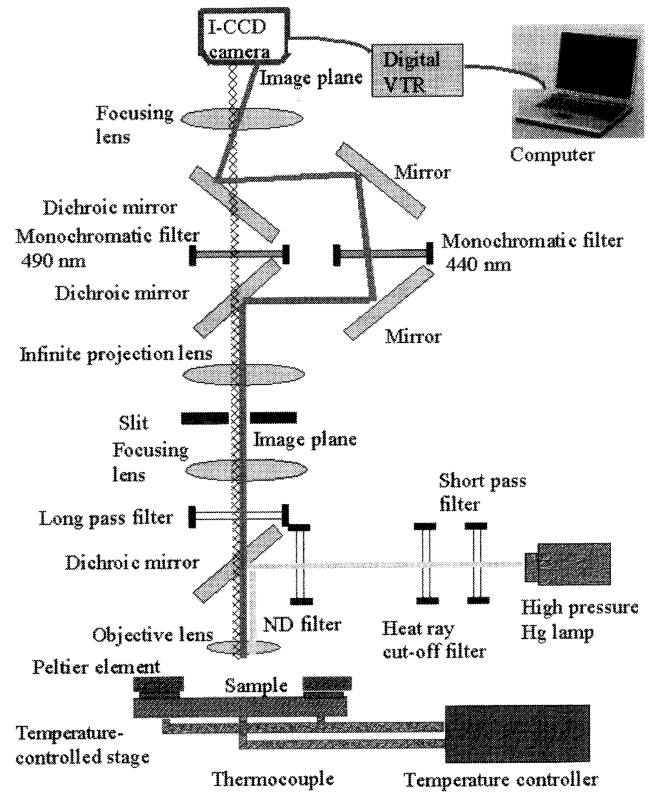

Fig.4 Optical system of microscope for video rate generalized polarization (G.P.) imaging.

G.P. of environment sensitive dye, Laurdan, was calculated from the emissions at $440 \mathrm{~nm}$ and $490 \mathrm{~nm}$ (Ref.3375). The fluorescence images of $440 \mathrm{~nm}$ and $490 \mathrm{~nm}$ were arranged on the plane of CCD chip, and recorded by digital video recorder. G.P. image was calculated from the two images by use of personal computer.

これは，脂質の生合成が行われる小胞体とゴルジ 体の領域で膜流動性が増加しているものと想像で きる.さらに, 細胞のアポトーシス現象について, その過程が膜の流動性変化に対して，どのような 時間的な関連があるかを顕微鏡下に観察して解明 することを試みた。過酸化水素で誘導したPC12D 細胞のアポトーシス過程では, 処理時間に依存し て, 処理時間6時間からCaspase3の活性が上昇し, 12 時間からDNAラダーが形成され，24時間から 核の形態変化が観察され，一方，ホスファチジル セリンの細胞表面への表出であるAnnexin Vによ る染色性は2時間から見られた。また，膜物性顕 微鏡画像化装置で観察した膜の流動性は過酸化水 素水処理後 2 時間まで時間とともに増加し，その 後は変化していなかった。過酸化水素処理で誘導 したPC12D細胞のアポトーシスの過程では膜物性 の変化が他の現象に先行して生じるという興味あ

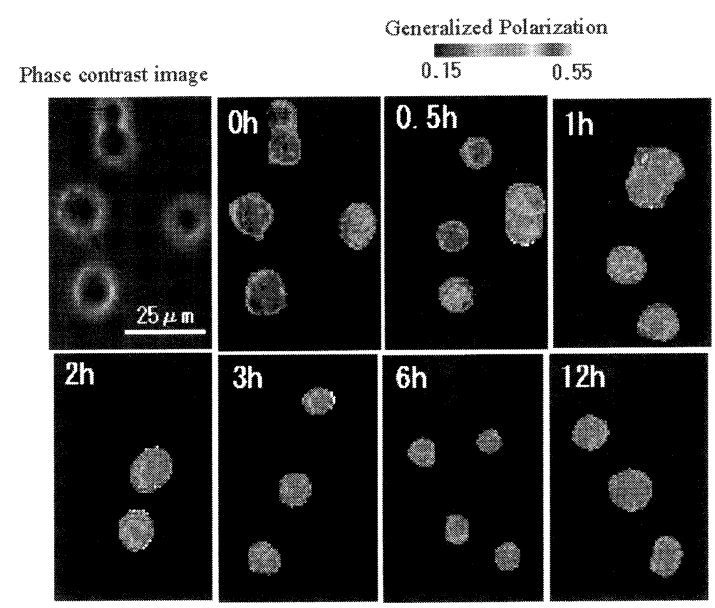

Fig.5 Microscopic G.P. images of PC12D cells in different stages of apoptosis.

Apoptosis of PC12D cells was induced by $0.5 \mathrm{mM}$ $\mathrm{H}_{2} \mathrm{O}_{2}$ in the culture medium. Each phenomenon was observed in apoptosis process in the following times; sensitivity to annexin $\mathrm{V}$ for $2 \mathrm{~h}$, increase of caspase 3 activity for $6 \mathrm{~h}$, formation of DNA ladder for $12 \mathrm{~h}$ and morphological change of nucleus for $24 \mathrm{~h}$. The cells, grown in the medium containing $\mathrm{H}_{2} \mathrm{O}_{2}$, were stained with $10 \mu \mathrm{M}$ Laurdan at $37{ }^{\circ} \mathrm{C}$ for $30 \mathrm{~min}$. Top left: phase contrast image of PC12D cells just after the addition of $\mathrm{H}_{2} \mathrm{O}_{2}$. Photographs shown in a series were taken at the indicated time and G.P. images were obtained by computer calculation.

\section{る知見が得られた(Fig.5 $)^{29)}$.}

\section{6. 相分離現象の実時間膜物性画像化顕微鏡による観察}

生体膜の基本構造となる二重層膜を形成する脂 質分子は集合体として統計熱力学的な物性である 相転移と相分離を示す。これらは脂質膜の基本的 な物性であり，膜蛋白質との相互作用を介して， 生体膜の機能に影響を及ぼしている。相転移は大 きな物性変化であり, その観察は生体膜でも難し くはない.しかし, 相分離は物性の異なる領域を 空間的に分離できる分解能が必要であり，容易で はない．作製した装置を脂質二重層形成脂質と非 二重層形成脂質の2成分系である DMPC/DMPE (1:1)の巨大リポソーム $(\phi \fallingdotseq 35 \mu \mathrm{m})$ に適用して, リアルタイムで膜物性の顕微鏡画像化観察を行っ た。その結果，顕微鏡下に相分離を観察すること 


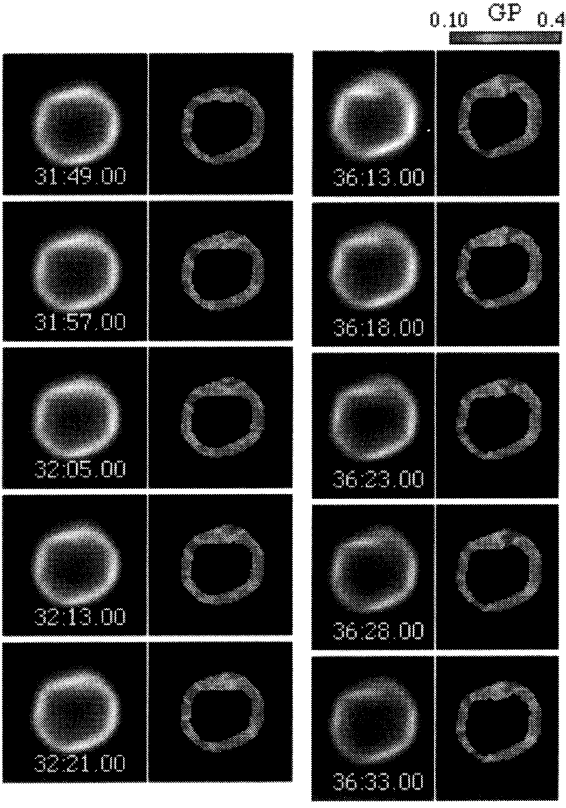

Fig.6 Phase separation of DMPC/DMPE (1:1) giant liposome observed by G.P. imaging.

Giant liposomes of dimyristoylphosphatidylcholine and dimyristoylphosphatidylethanolamine (molar ratio 1:1) containing $1 \mathrm{~mol} \%$ Laurdan were prepared by hydration in $2 \mathrm{mM} \mathrm{CaCl}_{2}$ solution. Representative microscopic images of selected from a series of video rate images.

ができた。得られたG.P.画像を解析すると巨大り ポソームの直線的な部分の流動性の低い領域と曲 率が大きく流動性の高い領域に分離していること が確認された(Fig.6).

\section{7. おわりに}

「百聞は一見に如かず」“To see is to believe.” 古今東西を問わず，直接に見ることが出来れば理 解し易く説得力もあります。レーザー，放射光， CCDカメラ，コンピューターサイエンスなどの 技術革新は，多様な分野で‘見る’技術を発展させ ており，今後，システムとしての生体膜の機能は 視覚的な研究で解明が進むものと期待されます。

\section{文献}

1) Singer J, Nicolson GL: Science, 175 720-731 (1972)
2) Sandermann H Jr: Biochim. Biophys. Acta, 515 209-237 (1978)

3) 大木和夫, 野澤義則 : 油化学, 30,636-642 (1981)

4) 実験医学増刊14 (1996)「脂質研究の新展開」竹縄忠 臣編

5) Hanski E, Rimon G, Levitzki, A: Biochemistry, 18 847853 (1979)

6) Jost PC, Griffith OH: Annal.New York Acad. Sci, 348 391-407 (1980)

7) O.G. Mouritsen OG, Bloom M: Biophys. J., 46 141-153 (1984)

8) Ohki K: Biochem. Biophys. Res. Commun., 164 850856 (1989)

9) 大木和夫：日本物理学会誌, 49 369-373 (1994)

10) Caffrey M, Feigenson GW: Biochemistry, 20 1949-1961 (1981)

11) Cornell B: Biochemistry, 30 5881-5888 (1991)

12) In't Veld G, Driessen AJM., Op den Kamp JAF: Biochim. Biophys. Acta, 1065203 (1991)

13) Ohki K, Tamura K, Hatta I: Biochim. Biophys. Acta, 1028 215-222 (1990)

14) Adachi T, Takahashi H, Ohki K, Hatta I: Biophys. J., 68 1850-1855 (1995)

15) De Krruijff B: Nature, 386 129-130 (1997)

16) Van der Does C, Swaving J, Van Klompenberg W, Driessen AJ: J. Biol. Chem., 275 2472-2478 (2000)

17) Garab G, Lohner K, Laggner, Farkas T: Trends in plant science, 5 489-494 (2000)

18) Israelachvili JN, Mitchell DJ, Ninham W: Biochim. Biophy. Acta, 470 185-201 (1977)

19) Ohki K, Sekiya T, Yamauchi T, Nozawa Y: Biochim. Biophys. Acta, 693 341-350 (1982)

20) Zha X, Pierini LM, Leopold PL, Skiba PJ, Tabas I, Maxfield FR: J. Cell Biol., 140 39-47 (1998)

21) Devaux PF: Biochemistry, 30 1163-1173 (1991)

22) Endo T, Kobayashi T, Ohki K: Exp. Cell Res., 228 341346 (1996)

23) 遠藤高帆, 大木和夫：膜, 21 334-340 (1996)

24) Sakai N, Sasaki K, Ikegaki N, Shirai Y, Ono Y, Saito N: J. Cell Biol., 139 1465-1476 (1997)

25) Kishimoto A, Takai Y, Mori T, Kikkawa U, Nishizuka Y: J. Biol. Chem., 255 2273-2276 (1980)

26) Yang L, Glaser M: Biochem., 34 1500-1506 (1995)

27) Parasassi T, De Stasio G, d'Ubaldo A, Gratton E: Biophys. J., 57 1179-1186 (1990)

28) Ohba T, Kiuchi T, Kamakura Y, Goto A, Kumeta T, Ohki K: J. Biosciences, 24 (S1) 117 (1999)

29）田中 拓，木内 泰，大場哲彦，大木和夫:脂質生化 学研究, 44 259-262 (2002) 